\title{
TRIGGERING CHANGE: Police Homicides, Community Healing, and the Emergent Eventfulness of the New Civil Rights
}

\author{
MEGAN RASCHIG \\ University of Virginia \\ (D) http://orcid.org/0000-0002-2299-5198
}

In the gray May days following the murder of a migrant lettuce picker named Osmar Hernández by a Salinas Police Department officer, a small but growing cadre of protesters stood at the edge of the supermarket parking lot where his slain body had lain too long. They emphatically waved signs at the busy intersection, exhorting drivers to honk for justice. I had driven by, fascinated by the asyet-unseen spectacle of protestors in this tense agricultural city near the Central Coast of California, and honked, but kept going, with somewhere else to be. But when Shi passed the same group that same day, she stopped right away. The lifelong Salinas resident, former Sureña, ${ }^{1}$ and present-day facilitator of a women's healing circle, parked her blue Mustang to talk to the people she did not yet know and find out what they were about. There was one person there she did recognize instantly: Wera, her old homegirl.

It had been ten, maybe fifteen years, since they had last seen each other, "in another life," back when they were both "gangbanging solid," as Shi told it. Since then, Wera had dropped her placaso, her gang-given nickname meaning White Girl, and been reborn as Tara on the day she gave up alcohol. Both had fallen out of the active gang scene while never renouncing it, attempting to dwell differently in resolutely established local conditions. But beyond recognizing Tara's blonde hair, pale skin, and strong walk, Shi further felt she recognized all 
that both had been through - all the deaths they had grown up and lived with that had to be abided, "taken like a G," in this youth homicide capital of California - as intricately involved in their respective decisions to stop at that initial protest. ${ }^{2}$ She saw these many earlier deaths as traumatic events, and the concomitant triggering effect Hernández's death had on each of them as spurring her and Tara's subsequent engrossment in emergent local responses to police violence.

Part of me chastised myself, after the fact, for driving past that protest at Hernández's death, as if it was not the most important place for me to be when I was studying the politics of health and healing in East Salinas. Like Shi, I should have stopped. I should have let it disrupt my plans. As one of the first instances of direct action I had seen in six-odd months of doctoral fieldwork, the protest made me fear I had missed an "event" in the Badiousian sense, a decisive moment when the scope of what is possible shifts, when politics happen and when the social changes (Badiou 2012). But as a white Canadian graduate student from a European university, new to the United States and its particularly insidious disparity in life expectations and experiences along the lines of race, class, and gender, I did not grasp the same scope of that protest or murder as did Shi or Tara. It did not strike me that this blatant state disregard for Latino/a life constituted a flare-up of the much more ongoing and subtle, but still lethal, abandonment of Mexican Americans in this notorious city, one beholden to the agricultural industry and embedded in carceral California (Gilmore 2007). In contrast to the Badiousian event that ruptures the world for all, this protest and Hernández's death resonated as differently evental to those differently positioned and "plump[ed] for" it (Humphrey 2008, 372).

In this article, I argue that such deaths - and other police-involved homicides of black and brown men and women in the United States - can bring longsimmering communities like East Salinas to a boil for reasons beyond the straightforward injustice of police disproportionately killing people of color. Such deaths can coalesce, illuminate, and ignite a range of generational and particular experiences of the lethal exhaustion of being both underserved and under suspicion by the state and its agents. Here, this means the enervative effects of persistent racial profiling and militarized policing, the unmitigated exploitation of the undocumented by slumlords and field bosses, uneven economic opportunities, unwalkable, unlit streets and cracked sidewalks, underresourced schools placed in dangerous proximity to pesticide-laced strawberry fields, and so on. These less spectacular instances of disregard and disposability have not been made into events in that Badiousian sense, but are simply born from the kind of quasi-evental 
everyday ongoingness characterizing denigrated and criminalized lifeworlds (Povinelli 2011; Berlant 2011; Cacho 2012).

Lauren Berlant (2007, 759) describes ongoingness as a mode of living characterized by "getting by, and living on, where the structural inequalities are dispersed, the pacing of their experience intermittent, often in phenomena not prone to capture." Shi and Tara, and others in East Salinas, could be triggered by that protest at these new deaths through their longue durée endurance of ordinary state disregard and criminalization, palpable (or only barely prone to capture) in what Elizabeth Povinelli calls quasi-events: those "more minute happenings" (Povinelli 2011, 13) that are not equally or always registered, the structural enervations listed above, or the microaggressions or subtle everyday struggles that might "never quite achieve the status of having occurred" (Povinelli 2011, 13) have a collective and cumulative effect. They wear people down. This temporality of ongoing exhaustion contours the conditions of sociopolitical possibility: the exhaustive, however relentless, generally does not demand an ethical, public, or political response the way the spectacular does.

In a setting often described by locals as inducing chronic traumatic stress disorder - as though the conditions of life itself are so fundamentally and endlessly disruptive as to render disorientation the standard - triggers constitute a key genre of historical duration for viewing and processing the historical present (Berlant 2011). They point to the ways people perceive and actively frame politics-inprocess. An emic term, triggers evokes a kind of in-the-worldness not directly linked to culpability but to being caught up in an already implicating world, a precarity fueled by the ease with which life or livelihood can be threatened, and an exhausted, fraying hypervigilance. Like the rupturing event and the steady certainty of progress as models of history and social change, triggers suggest a particular cadence of how sociohistorical conditions are sensed, problematized, and shifted, bringing lived-through events into sudden relation with each other by reigniting prior reactions to painful circumstances in new moments. Bracketing phenomena and encounters as triggers renders a range of quasi-evental happenings available for ethical response, accomplishing the ethical work of temporalization involved in any living-out and interpretation of social action (Zigon 2014). ${ }^{3}$

As such, some triggers give tangible coordinates to the struggle to bring about social change or the effort of endurance among strained individuals and communities in a politically fraught moment in late liberal America (Povinelli 2012). They demand to be taken seriously. In the past several years, trigger warnings on potentially upsetting texts have faced virulent critique in a range of 
liberal publications and institutions as indicators of coddled minds, treating them as a politically correct default to safety that limits intellectual and emotional challenge and growth (Coyne 2015; Lukianoff and Haidt 2015). However, debates over the value (or scourge) of trigger warnings elide an essential point about disparate racialized experience and political action today, as I discuss below.

In what follows, I trace a bundle of triggers across three police homicides and four Salinans' lives. I foreground the responses generated in each case as particularly situated with local conditions in Salinas, and politically resonant with the emerging concerns of the New Civil Rights period associated with Black Lives Matter (Kang 2015; Day 2015). ${ }^{4}$ The instances of triggered activism below highlight the adjustment and creativity necessary among criminalized communities whose residents cannot occupy the rights-bearing, self-contained, and self-interested subject-space of liberal politics, and thus often engage in activities, build organizations, and nurture spaces that stretch and disrupt our ideas of the political (Cacho 2012; Ralph 2014). Turning to more temporally complex ethical projects in relation to the disparate eventfulness of state violence, how might we shift the temporal frames we use to grasp emergent political processes, the newness of the New Civil Rights movement as it unfolds in critical settings like Salinaswithout merely recuperating or absorbing those fragile projects in the same teleological tropes of history?

\section{HEALING HISTORY AND RECALIBRATING ETHICAL ACTION IN SALINAS}

As I would learn, Hernández's officer-involved death provoked a temporal tripwire for both Shi and Tara, in the sense that what happened to make them stop and keep them at that corner was not just one particular death, but a sudden, jangling cacophony of many other deaths already endured and left unresolved, lives shrugged off or taken by the police. "For our people, this is not about the one or two murders," my friend Juan explained to me later that day, trying to help me understand why Shi reacted so dramatically to this killing-her absence at the afternoon's meetings, her shrill and erratic responses to my calls and texts, her sudden impassioned demonstrating at the streetside - of another police homicide of a man she did not know. "It's a social, historical thing, police brutality. It takes people back to a place where they're not their best."

I knew Juan and Shi as the founders and leaders of the city's two healing collectives, Motivating Individual Leadership for Public Advancement (MILPA) and La Colectiva de Mujeres, with whom I was spending much of my time in 
East Salinas. These collectives had been formed and funded only months preceding these homicides as part of a long-term philanthropic project in the city, Building Healthy Communities. ${ }^{5}$ Prior to this project, a considerable history of philanthropic investment had already produced an elaborate and celebrated, if fluctuating, community infrastructure rooted in César Chávez and the United Farm Workers union's presence in the 1970s and amplified through subsequent late liberal regimes of state disinvestment in public health. Health-oriented community-level programs of various stripes saturate East Salinas as a key means of managing the underserved, illicit, or otherwise-hard-to-reach Latino populace, categorized as farmworkers and gang members, targeting their lives and the community at large for improvement at the same time. While the relentless responsibilization and narrow moral scope of these programs can give rise to fatigue or resentment among their participants, the healing collectives immediately struck a different chord for most members, and a generally conservative philanthropic setting could emerge as a key site of political possibility.

The Colectiva and MILPA were the upstarts in the community, considered dramatically different than other local health-oriented organizations by their participants. Their freely accessible programming primarily consisted of healing circles, but also visits to a nearby sweat lodge for those interested, and an increasingly active presence at meetings held by the city, county, or sheriff's departments related to education, public works, or criminal justice concerns. Each of these modes of engagement was considered essential for healing, and the combination felt radical. "This has never been done before" in Salinas, Shi told me with astonishment about the Colectiva's healing circles a few months into their implementation. "It's actually history."

I was a member of these collectives before I was also their researcher. From the twice-weekly healing circles of the Colectiva de Mujeres especially, where kernels of ethically difficult and affectively ambiguous experience were "checked in" or disclosed and calibrated into new moral orders, I was becoming sensitized to the eventfulness of members' lives in East Salinas, the stakes of their healing, and the stratigraphy of their scabs. With consistently high violent homicide rates for more than a decade in this California farmtown-gangland, the persistent threat of death brought dramatic rhythms, expectations, and stakes to life for its 155,000 inhabitants, 75 percent Latino/a, one-quarter earning less than $\$ 14,000$ per year (Dieng, Valenzuela, and Ortiz 2016). ${ }^{6}$ Many members of these healing collectives, like Shi and Tara, were formerly gang-involved and had lost children, friends, or family members either on the streets or to the judicial system. They dealt with 
the effects of these conditions daily, in myriad expressions increasingly framed in terms of healing from old wounds.

Healing had come to constitute an emergent ethical imperative salient across the city, where almost all third-sector programming and social action was funded in terms of health. This shared imperative to heal offered imaginative resources and a purposive orientation to the need to know one's triggers as they might arise at any given moment. Critically, their healing circles were sites at which triggers could be anticipated and explored, brought into consideration with others' similar experiences, and sometimes even further with a broader critical consciousness of U.S. race, class, and gender inequality. For example, Naomi, a white middleclass Mujer who worked at another Salinas community organization, once made a statement in circle about an event of sexual assault. When translated into Spanish, it triggered a flood of feeling in another Mujer, an undocumented Mexicana named Guadalupe. Guadalupe had never previously been able to articulate her own similar experience despite its determining effects in her life, but after $\mathrm{Na}$ omi's disclosure, she could acknowledge it and reflect on the fact that such violence against women occurred across race and class. Some weeks later, she described realizing the traces of this abuse and addressing its perpetuation with a current boyfriend, modeling for the others in the Colectiva what healing such a trauma could look like. In these collectives' fledgling politico-therapeutic spaces, being triggered could initiate transformation, rather than constituting an act of smoothing over.

The wider horizons of these collectives' vigilance against triggers suggest the temporal dimensions of world-building as political action coalescing from an array of moments. Such action can be constrained by the world-destroying effect of quotidian, chronically traumatizing conditions of poor and criminalized communities. As the psychoanalyst Robert D. Stolorow $(2011$, 54) writes, "trauma destroys time." What he calls portkeys, akin to what both Salinans and I call triggers, are those encounters with worldly stimuli that give the sudden sense of being transported to another time and location, which “can fracture or obliterate one's sense of unitary selfhood" unfolding across linear time, returning one "again and again to an experience of traumatization" (Stolorow 2011, 55). But such traumatization, in its repetitions, clearly also generates time. What might begin as an edgy, atmospheric suspicion that something "is gonna crack off" at an otherwise peaceful civic meeting, as Daniel, a member of MILPA, put it, or that public servants "are trying to gangbang on [you] at the city hall," can lead to a make-orbreak moment. In this moment, as my interlocutors narrate it and as I observed, 
one either falls back and gets sucked into old, devastating ways or chooses to bracket that reflex, situate it in terms of what-has-been, and decide in some way to break with that resurgent, but redundant, temporal trauma.

Daniel's recounting of one such make-or-break moment illuminates the worldly and generative nature of the often individualized fragmentation and dissociation of trauma (Stolorow 2011, 53). His reflections on a municipal meeting the night of the Hernández shooting came as he and I, as well as other MILPA and Colectiva members, gathered in a small office to organize a collective response to the police homicides, in the process of descargando (checking in) that unfailingly began not only each healing circle but also every organizing meeting either collective held. ${ }^{7}$ Daniel continued, “I just freakin' almost lost it, you know what I mean? If it wasn't for these girls that were like, hey Daniel, come talk to the media real quick, I think I probably would've ended up getting arrested yesterday for some stupid stuff, you know. Because he really pulled my triggers," he elaborated, sketching the perhaps unwitting intervention performed by "the girls" that called him back to himself as the Daniel they knew, the Daniel who needed to speak with the media as a smooth-talking MILPA representative, rather than the shotcaller in a local street gang he once was. He added, weary but determined, "we have to be careful not to get sucked in by all the things we did before," or that which may be an appropriate and likely response in other circumstances.

As Daniel temporalized it, triggers could signal moments of what Jarrett Zigon (2007) calls “moral breakdown,” shifts away from one's nonreflexive way of morally being-in-the-world, demanding an ethical response. In the grips of what often feels more like repetition, these are creative and productive moments of reflection and decision, critical moments in which individuals and their ethical and political projects may open onto an otherwise that has the potential to improve their conditions of dwelling. Still, despite their interpretive efforts in these healing collectives, my friends' triggered responses to stimuli like these homicides - and there were many - offered brusque reminders of the effort of endurance amid the slow erosion of life here. Rather than leading to a moral breakdown, triggers could also remain an arresting affective resonance, a falling-deeper-into or outof-the-world, unregistered as an event: "the same shit."

Whether, how, and when such a happening is narrated as a trigger demonstrates the ethical action of temporalization involved in everyday discourse. As Zigon (2014, 448) writes about the temporalizing work done through narrative, "by creating a particular temporal relation to a singular ethical moment, one is able to create particular possibilities for acting unique to the singular ethical 
moment." Such moments can be narrated and renarrated, post facto, throughout the process of coming to terms with one's complex, intensely affective relational history with the state and its police. The recalibration of these affective historicities into new ethical orders enables new forms of political action understood as intervening on the relational and material conditions of the local world - even if this intervening in the world sometimes means disengaging from it.

"Why am I really doing this, like, if I ask myself?" Shi later mused, reflecting on her recent, impassioned activism against police brutality since reencountering Tara over Hernández's death and gesturing to this generative quality of her trigger. "It's for a lot of the things my friends have went through and have never had justice. Like a lot of my friends have been murdered [in gang-involved circumstances], and their parents still suffer, because they're all cold [unsolved] cases." This, too, was state disavowal: the nonevent of lackluster police investigation, the quasi-event of that queasy feeling of a death unsettled and a life thereby diminished. "I really feel like a lot of it has to do with a lot of the injustice that already had happened, that I didn't see before, you know?”

"And," Shi continued, her voice getting louder, "it's even more of an injustice because law enforcement never really solved none of these cases. Or they didn't give a fuck about it! And these were people that we fucking loved!"

In her rising anger, I could hear the echoing trigger, the resurgence of feelings and fidelities, the anguish of lives not mattering to the state despite being loved. That anguish and the fear of feeling it again even pushed her to move out of the East Side to a different neighborhood to be "less known," she explained, after distancing herself from the Sureño gang activity that still suffused her relationships. But in 2014, as a facilitator of La Colectiva de Mujeres, in the midst of her own ethical process of healing and compelled by this triggering, she found a means to transform that affective condition into ethical action. In doing so, alongside others in the collective, she became one of the most active local figures in the days, months, and years following these police homicides.

"So I think a lot of it," she continued, the edge in her voice ebbing, "a lot of the frustrations and the anger, really came from some other shit that we had from before. Because we never had that opportunity to really talk about it, it was just, it happened, and shit. Move forward.”

\section{EXHAUSTION AND THE NEW CIVIL RIGHTS}

What made the opportunity to finally "talk about it" in East Salinas possible was not only the bundle of triggers set off by the police homicides, and not only 
the salience of the healing circle's reparative approach to past experience, but also the sense of a historical moment acutely taking form that summer of 2014. The police killings in Salinas happened both before and after Ferguson, the massive uprising at the officer-involved death of Michael Brown on August 9, 2014, designated as the cradle of the organized Black Lives Matter movement against police violence and institutionalized racism (Bonilla and Rosa 2015). My friends from the healing collectives followed the response to Brown's murder in Ferguson closely as it saturated the news coverage, expressing solidarity but also a frustrating feeling of déjà vu - that already happened here, that happens here all the time, they cried, as our everyday topics of state violence and police militarization became broadly circulated in mainstream discourse. "Before it happened, it had happened and happened," the poet Claudia Rankine $(2014,116)$ writes of the Rodney King beatings, the blatancy of this particular beating overshadowing the backdrop of other repeated but unacknowledged occurrences.

In East Salinas, many expressed a compounded struggle. As was pointed out to me repeatedly, Latino/a communities endure comparable conditions of suspicion, criminalization, and exhaustion as African Americans, facing life-extinguishing or world-crumbling vulnerabilities in their daily lives, intensified in post9/11 securitized state hostility toward undocumented migrants as terrorist figures. Latinos/as exist in significant concentrations in the criminal justice system, and while they are killed by police at rates lower than African Americans, their incarcerations and murders are still devastating for hundreds of thousands of people across the country. ${ }^{8}$ Concerns with migrant detainability or deportability often receive more attention than police violence within Latino/a communities and in mainstream America, constraining the ability to speak up or organize publicly (Santa Cruz, Vives, and Gerber 2015; De Genova 2007).

The point of making such comparisons was not to engage in a kind of dueling "oppression Olympics," as my informants would say, but to indicate how their communities have been differently constituted through history and geography and situated elsewhere in the racial imaginary, a coalescence of colonialism and socalled crimmigration, or migrant illegality, at the periphery of slavery and republicanism (De Genova 2005). When acknowledged, these conditions can give rise to questions of why a more organized Brown Lives Matter movement has not, it appears, taken shape, a lament in line with the discursive trope of the Latino Sleeping Giant yet to wake up to its power (El Nasser 2015; Beltrán 2010). More productively, paying attention to local ethical processes and projects, like the East Salinas healing collectives and circles, and lived temporalities, like ongoing ex- 
haustion and triggers, illuminates the forms of personal and political action that are more possible and involve less vulnerability for these communities, both particular to local circumstances and influenced by broader national and racial dynamics.

The ways in which time is made and the political gets stretched in communities like Salinas offer solutions to the political impasse of late liberal America, where the idea of progress is little more than a broken promise, where the "old coordinates of left, right, and center seem profoundly unmoored" (Comaroff 2011, 102), and where theorists and activists call for new terms and tactics of struggle (Brown 2001, 2015; White 2016). Further, what is at stake in this tentatively titled New Civil Rights period of struggle against racialized state violence is not identical to the concerns of the old Civil Rights Movement centered in the 1960s. ${ }^{9}$ Today's New Civil Rights movement gestures toward an increasingly perceptible and intolerable critical node of contention: the enervation, disposability, and ungrievability of black life, and the institutionalization of a racist and dehumanizing gaze that perceives black life as an inherent threat to other life in general, and to white privilege in particular (Day 2015; Butler 2015). In a situation of structural abandonment, simply to exist in public entails its own precarity. "This need to be always on guard" against violence physical, structural, and discursive, as the essayist Ta-Nehisi Coates $(2015,90)$ puts it, is "an unmeasured expenditure of energy, the slow siphoning of the essence" that contributes to the "fast breakdown of our bodies." Coates describes the eventfulness of exhaustion that wears people of color down, the ongoing traumatization and numbing that can doom any burgeoning efforts to do or be otherwise- but that can also provide fertile conditions for a genre like the trigger or an idiom like healing to take root.

The lived temporality of exhaustion in individuals and communities of color, considered as a focal grievance of the New Civil Rights era, casts mainstream controversy about trigger warnings into new relief. The trigger warning is meant to secure readers against the risks involved in being triggered, alerting them that they are about to encounter elements that may resonate with lived experiences, thereby upsetting them or even causing reactions akin to post-traumatic stress disorder. To some critics, the trigger warning signals the moment at which the critical potential of challenging readings of classic texts melts into a moralism of sanguine safety. It is decried as a simultaneous politicizing and depoliticizing move designed to protect humorless or overly sensitive readers or consumers from 
unwanted disruptions to their well-being, threatening free speech and divergent views in educational environments (Coyne 2015; Lukianoff and Haidt 2015).

Yet among communities facing daily, overt terror, as well as subtle and slowly exhaustive traces of institutionalized racism - the "haunting" (Gordon 2008) of disparity and marginalization in an ostensibly postracial era-triggers arise from happenings in the world rather than from textbooks. They do not come with warnings. This makes the condition of being triggered particularly vulnerable, as well as potentially productive: triggers indicate not simply psychologized stutters but breakdowns of the ongoing present, generating moments of affective and ethical response. As demonstrated below, triggers and their taking up in local relationships of care and accommodation offer glimpses of how people open up to an otherwise and generate it in their actions together. Like the practices and relationships of accommodation engaged in by those driven to madness through intimate loss that Laurence Ralph (2014) outlines in his work in Eastwood, Chicago, the circulation and management of grief and rage, the ethical process of becoming aggrieved through emergent communal formations of care, illustrate the worldly and social nature of conditions too often pathologized, depoliticized, and dismissed. What results is a politics of eventfulness in which participants reveal and contest discrepancies in perceptions of what, precisely, is happening.

\section{HAPPENING}

“This just doesn't happen here," the Salinas police chief Kelly McMillin claimed in a news clip, in response to another officer-involved shooting on the streets of Salinas mere days after the previous one. This time the victim was a man named Carlos Mejía.

I listened as the CNN reporter repeated the chief's words twice, discussing the shooting that subsequently fueled a much filmed protest-turned-riot:

He [McMillin] says they do not have a lot of police shootings, but acknowledged that there was this one on Tuesday [May 20, of Carlos Mejía] and there was another one on May 9 [of Osmar Hernández] that was very similar to this, but he goes on to say that this is just not something that happens there. . . . This is the third of the year, but the police chief is saying they don't have a lot of this, that this just doesn't happen here. 
Grappling to understand the uproar and outpouring of East Salinas residents' anger at these homicides, Chief McMillin's words sounded like an attempt to render these deaths anomalous and exceptional rather than repeated or structural, an attempt to downgrade the scale of the police or civil response needed. McMillin's diminution of these homicides, which at this point were indeed suspiciously starting to pile up, stood in contrast to Shi's response to the homicides as we drove toward the scene a few hours after Mejía's death. "It's too much already, it's just too much," Shi sighed, trailing off. "I just can't. . . ."

I was at the wheel while Shi was trying to keep herself calm, having suddenly been triggered earlier that morning by the news of this (yet another) homicide on the East Side. She and I were coming from a meeting that we had intended as Colectiva de Mujeres program planning time, but instead mostly spent with Shi alternating phone calls with two old friends and now Colectiva members, Yesi and Luisa, leaning in every so often to give us more details on the latest death. "They shot, the police shot a paisa [recently arrived Mexican migrant] in front of Delicia's, that bakery up on Sanborn. Flaca lives right down the street from it. She lives where the police tape ends." She was referring to Yesi and Luisa as Flaca and Gata, their old placasos.

Ending the meeting there, in the throes of being triggered by yet another killing, Shi felt too freaked out and nervous to handle the wheel and asked me to drive her to Yesi's. "It's too much already," she sighed repeatedly as we drove there. "It's just too much."

Arriving at the perimeter of the police tape, we found Yesi out on the front lawn, while her granddaughter whizzed about nonplussed on a tricycle. Yesi had run inside and locked all the doors when she heard yelling and gunshots, and immediately called Shi when she saw Mejía take the bullets, but now she was outside snapping photos and surveying the scene. We stood there too, talking to some of the men in ranchero hats sitting at the bus stop in front of the house, they sitting on their hands with shoulders tight, all of us quietly looking to the corner. Preschoolers hand in hand with young mothers slowly filtered home past the scene. Police milled about within the taped-off zone, one standing with arms on hips next to Mejía's lifeless, uncovered, and somehow handcuffed body.

Was there an exceptional edge to the ordinariness, or an ordinariness to the exceptionality? We all lingered by Yesi's house, gathering around smartphones watching the soon-to-be-famous footage her daughter's friend had taken of the cops' slow pursuit of the stumbling Mejía, filming it ourselves in case the original was forcibly blocked or deleted. The day went on like this. 


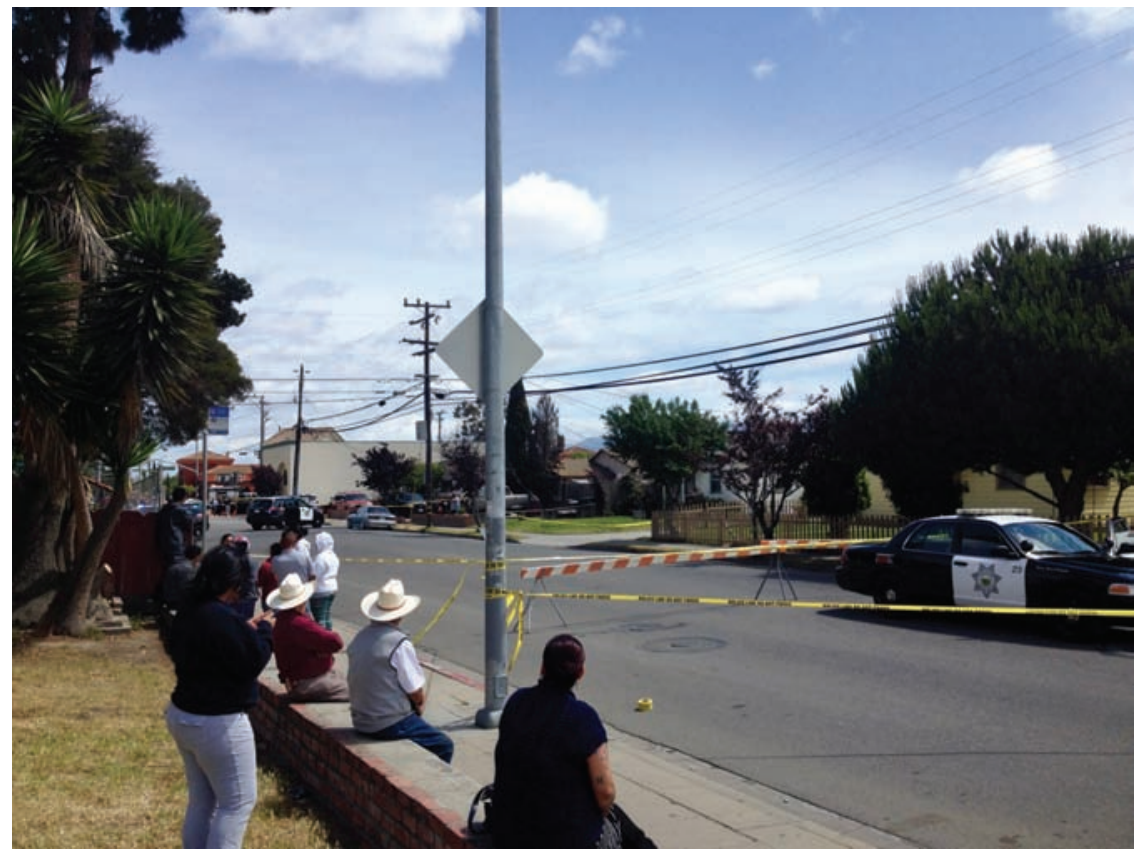

Figure 1. At the perimeter of the police tape, watching officers deal with Mejía's body down the street. Photo by Megan Raschig.

How can something claimed to "never happen here" also be felt to "be too much already"? To what extent were these deaths exceptional or ordinary, and how could they emerge as triggering, and as evental, in the oscillation between these conditions? Yesi's seemingly instinctive reaction to hide inside and reach out to Shi, and Shi's visceral anxiety and refraction of the Mejía death in terms of the proximate Hernández death and perhaps countless others, were aspects of resurgent affective conditions and attachments, assailing but also setting them in motion. Moving through their triggers, in part through their reorientation as belonging to an older generation of gang-involved women with a remaining claim to these streets, and in keeping with the ethical imperative to heal themselves as well as their community, Shi and Yesi shifted into a reflexive and creative mode.

These deaths, made differently sensible in the context of their participation in the Colectiva de Mujeres's twice-weekly healing circles, were different enough to lead Shi and Yesi, but also Tara and other Colectiva members, to go out the next day and stand at the corners of the bakery's intersection holding fluorescent signs and directing children in a peaceful demonstration of community stewardship. At the same time, these deaths were also "the same" enough that I could 


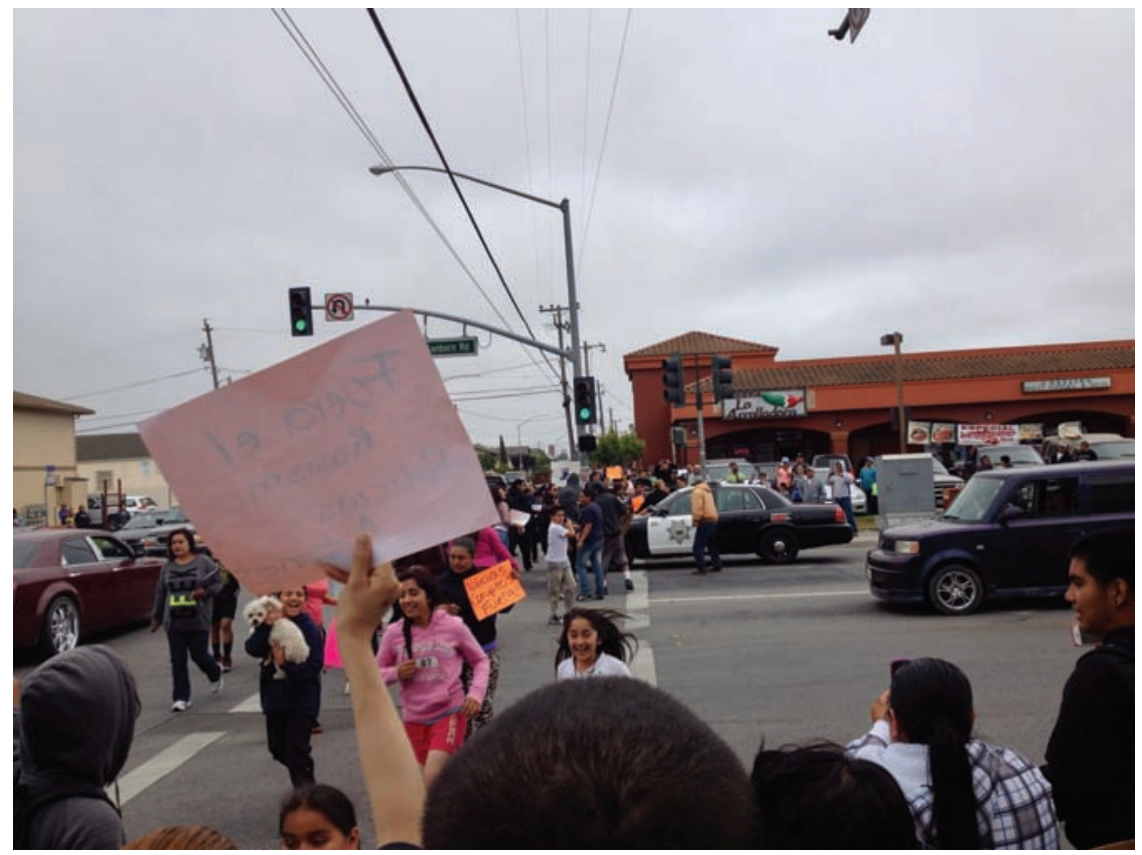

Figure 2. The ensuing protest-turned-riot, at the intersection in front of the bakery where Mejía was shot the day before. Photo by Megan Raschig.

ask a young woman at that rally, as it steadily turned into what would be eventalized as a riot in the frenzy of youthful energy and frustration and noise, if she'd ever seen anything like this before. With my gestures and gaze, I was referring to the protest and the hundreds of kids and teenagers pumping their fists in the air every time someone honked, expecting her to remark on its exceptionality as a political event. Instead, she responded, "Oh, yeah, it happens all the time. Last year it happened right in front of our apartment," she pointed a few blocks away. "A shooting. A couple guys were taken down right there."

Taken aback, I did not insist on the intended specificity of my questiondeciding that she had not, strictly speaking, misunderstood it. Rather, like Shi, Yesi, Tara, and likely many more, she apprehended Mejía's death and Salinans' responses to it along a different historical trajectory, one of structural disavowal and the abandonment of Latino/a lives, not of the romanticized and exceptional events of protest and politicization. What made these deaths exceptional was that they jangled into urgency a host of other unmourned and unsolved deaths that otherwise made up the ordinary. 


\section{ON DISENGAGEMENT: Being In and Falling Out of the World}

Their respective participation in the protest-turned-riot was just one effect of Shi's, Yesi's, and Tara's triggering; it also happened to be the most publicly recognizable. This protest became termed a riot in part because a quieter contingent left their rally counterparts and branched off at some point, ending up at a nearby community arts center where many MILPA and Colectiva members, myself included, hosted an impromptu public healing circle. These community-wide healing circles continued for a little while, but lost steam without producing recognizable results, though the twice-weekly healing circles by MILPA and the Colectiva went on. The women's circles especially saw themselves strengthened by these homicides, becoming critical sites for local women, like Tara and Yesi, to demarcate and work through their triggers, generating openings for them to get involved in healing themselves and their community, entwining their respective ethical processes glossed as recoveries.

In this section I explore the eventfulness of Tara's and Yesi's lives as it was refracted by their triggers and subsequent actions in relation to this period of police homicides. Stirred - triggered - by these deaths in the summer of 2014, these women came to frame their reactions in terms of still needing to do a lot of the healing work from those erstwhile years. During these years, each woman had made multiple attempts at moving on from her gang involvement. Each struggled to maintain a sense of contemporary moral and existential integrity for herself - to not fall apart, or fall too far into or out of the world - in the face of the beckoning repetition of death all around. Their responses manifest the vulnerability of being triggered, as does the critical attention needed for the way these states are accommodated in local ethical formations, such as emergent social projects like healing or institutions like the Colectiva de Mujeres.

In the years before reuniting, Tara had endured waves of incarceration, probation, and addiction recovery. Invited by Shi as they rekindled their friendship after Hernández's death, she joined the Colectiva for much of the summer of 2014, adding it to her busy schedule of both mandated and voluntary addiction treatment and personal growth. She was just finishing a stint at a privately run probation authority, and I would often pick her up to shuttle her between her workplace, her Alcoholics Anonymous sessions, the Colectiva's healing circles, and weekly city hall meetings. Very open about what she continued to endure, Tara spoke of living through countless deaths of friends and family, both near and far. In particular, her husband was murdered while she had been locked up, leaving her without a sense of closure, let alone the chance to mourn. She mis- 
carried during that time, due to "stress and sorrow. I bottled it all in," she told a group of us at a meeting to organize a Colectiva response to the police homicides, "and when something like this happens, it gets all stirred up again. The danger is that it might explode." I constantly heard apprehensions like this around the triggers, the fear of slipping back into old ways, the fragility of recoveries, and the devastating rhythms that threaten to become a life's repeated refrain.

Yesi had joined the Colectiva de Mujeres when Shi founded it months before the homicides, and despite her doubtfulness about "what kind of colorful people show up there," she attended "just to back [Shi] up." Yesi expressed happy surprise at finding that both she and Shi had "completely changed," and that they could now be "official friends without any, like, using each other, for money, for drugs, or to go fight somebody." Yesi, an energetic Mujer with an infectious and endless laugh, expressed a hard-won sense of recovery, patched together through various stints in rehab and prison. She had been free of heroin for fourteen years, citing it as her major recovery, though in that time she had been to jail numerous times for drug possession, sometimes on behalf of boyfriends. "I had to take the blame," she told me in an interview, "because you can't go telling on people, you gotta suck it up and take it like a champ." Her other major recovery was from her anger, a fire stoked by times spent in frictional clinical rehab settings, where "they wanted me to do stuff like beading and arts and craft stuff and you know, like, when you're trying to get yourself clean and you miss your kids and you're scared and you don't know what's gonna happen, and pretty much they just pulled you out of your world. . . ." She trailed off, pausing before adding that "as bad as your world is, that's your world and it's what you're used to."

Both Tara and Yesi went to the site of Mejía's death with Shi the day afterward, spending the afternoon equipping children and youth with fluorescent papers and slogans, and shepherding them safely across the traffic lights. Over the honking of cars and cheering of kids, Tara's ragged voice could be heard calling Cálmense!, “calm down!” Yesi took a more backstage role, taking photos and Facebooking the event the whole time, becoming a point of coordination for those near and far. As more and more youth, then adults, came and spread to the four corners, and as the day drew toward night, the energy shifted, becoming heavier, edgier. The cops showed up and the mood soured.

As Yesi related it to me later, "I went inside as soon as the cops got there. They were gonna like, do the whole pepper spray thing . . . when the riot gear came out, I was like, I think this is about time to go. . . . Yeah. And I knew Shi was gonna stay there, so I just took Shi's daughter with me. . . . I was like, I'm 
gonna be the bigger person and like, know when to stop," she laughed, "before I get jailed again.”

Knowing when to stop not just at that protest but for good, Yesi mostly stayed away from subsequent direct actions related to the police homicides, which other Mujeres participated in or even organized. She knew her triggers well but hadn't completely mastered their management, and she did not want to risk "all [she'd] accomplished": her stable job, a burgeoning romance, and important maternal connections with her granddaughters. Not wanting to be another statistic, and in loyalty for Shi and the Colectiva as "her thing," Yesi's actions of disengagement were less active but still indicative of her pursuit of becoming other than she had been. For example, during this same summer, while East Salinas was in disarray and Yesi was staying away from the group, she found out that someone had pulled a gun on her daughter. Her daughter was gang-affiliated but making her way out of this involvement, trying to stay out of jail. Yesi felt enraged that someone had threatened her daughter, telling me that she "called every Tom, Dick, and Harry that I know, that I know-know, and told them: 'my daughter, she's so-and-so's daughter, our daughter, we're known, and this happened. And it was a guy.' They're like, 'oh, tell us who it was so we can handle it,' right . . . but I didn't know, and she didn't tell me.”

Yesi soon found out that the person who threatened her daughter was the son of one of the other Mujeres in the Colectiva. Though still furious, she called off the hit, because "the healing circle taught me not to bring women down, because, you know, instant motherly reaction I would've been over there beating the fucking shit out of her because she can't keep her kid. But then, y'know, I had to take a step back, defuse the situation." Confronting the other Mujer about it later in a safe space, Yesi explained that, "me being the very . . . hitting person that I am . . . I stay away. Gotta suck it up, one more time. And I confronted her, but I . . . dude, I waited. I waited.” Yesi's job at a local strawberry-packing plant kept her busy during the Colectiva's scheduled healing circles, but "even if I could go, I wouldn't go, only because I wouldn't want to for some reason flip a switch," she said, using another common idiom for the effect of being triggered, as "then people are gonna be like, 'oh, yeah, see, that's what you get when you get a bunch of Mexicans together, all stereotypical, on the East Side, typical.' I don't want to be a stereotype!” She laughed. Even though Yesi stayed away from the circle and the Colectiva's activism, her apprehension and action in relation to her triggers during this time demonstrate a connection between her recovery and her sense of contributing to a changing, improving East Salinas. 
Tara, on the other hand, became a regular fixture at all protests, no matter which community group organized them or to what ends. Simply speaking, Tara was everywhere, addicted to the action, spilling herself out on her wordy protest signs, waving a white bandana at drivers, all the while howling, "Pítaleeee! Pítale, papá, no tengas miedo! [Honk! Honk, man, don't be afraid!]”. She could also often be found at the twice-weekly healing circles whenever she could arrange a lift, seeing the circle as a setting crucial to her ability to keep putting herself "out there" at protests, and to keep working through and with her triggers. She had an exuberant, playful presence, but in circle she often became stoic. Touching on some of the affective and ethical stakes involved in her grieving and activism, she once noted that "I feel so exhausted . . . I feel like some emotional stuff, about what's going on in our community, it brings it home, a lot, what's happened in my past. It brings up a lot of guilt . . . to do with, you know, everything, that life; I know people doing life behind bars, people I've lost that are now in heaven, loved ones . . . and I'm just feeling a lot of grief right now."

As Tara found ways to manage her exhaustion by "reaching for the [healing herb] sage instead of the bottle or the blunt," she faltered as other developments and dissolutions in her life impeded her ability to reflect, focus, and heal through the resurgent grief. Though she openly embraced as well as struggled with how to make sense of past deaths, she had distinct trouble with what I see as the ethical work of temporalizing these and other past quasi-events, articulating them as distinctive and chronologically related to other similar happenings (cf. Zigon 2014). One clear example came on a Thursday evening in early July as the Colectiva made what they called Life Codexes. In reference to the Mayan Codices, folded books filled with illustrated chronologies of important historical processes, each Life Codex had four folded panels, each available to hold a key event in the drawer's life. These events could be past challenges or victories (a rape, a marriage), or they could stretch into an anticipated future - getting a much-desired motorcycle, graduating from college.

These creative activities always seemed to go over well with the Colectiva de Mujeres, offering a change in atmosphere from the sacred and solemn healing circle to the chattier and more fluid artist's workshop. Chairs were pushed back and we all sprawled or sat on the floor, digging for markers in plastic bins, giggling at our drawings, but also becoming quiet and focused as we reflected on four things that had come to matter to who we felt ourselves to be. I looked over to Tara, sitting nearby, who was alternating between being boisterous and picky with the markers' shades, and silent with concern as she hovered over her still- 
blank four folds. She could not think of anything at first, feeling depleted by yet another recent police homicide in East Salinas of a man named Frank Alvarado. She likened herself to an emptied wine bottle. Eventually something came back to her, and she started to fill in the panels on her page. The first one simply said "PAIN," the third "HURT." She asked me to draw lightning bolts, in red and black, in between. Despite all the specific crises she had undergone, she could not compartmentalize and eventalize them; they all constituted a commingled haze of pain and hurt.

I take seriously this inability to eventalize in light of the progressive fading away of Tara from the Colectiva and the protests. She became ever harder to reach, without any stable address, her phone only working sporadically. My repeated efforts to contact her all failed, even as I left the field and continued periodic attempts to check in with her via Facebook (on which she was inactive for large periods of time). When I returned for a short visit to Salinas some seven months after leaving, among the first things I asked Shi was whether Tara was around. Shi responded no, she was not. As she put it, Tara "fell off."

"She what?"

"She fell off. She never got over the [Carlos] Mejía stuff. She got tripped up on it and stayed there."

\section{TEMPORAL TRIPWIRES}

In their own particular ways, the police homicides and the local imperative of healing opened a possibility for members of MILPA and La Colectiva de Mujeres to shift their long abidance of lethal state disregard toward a newfound ability to let past and emergent happenings take on a stronger and politically intolerable eventfulness. Through an apprehension of their triggers, Shi, Yesi, and Tara claimed the breach of a limit of tolerance and put this to political work by engaging in concerted ethical action and political engagement, whether positive and energetic (like engaging in protest) or negative (like staying away, as many did). Nurturing this understanding of their triggers from the space of the healing circle, these and other women consolidated the Colectiva de Mujeres into a prominent local organization for transformative healing and community engagement.

Still, I recognize that Yesi's and Tara's ways of working through their triggers might not seem to explain particularly well how social change happens. If anything, they seem to showcase one side of the spectrum of why certain projects proceed or certain worlds are grown and established, as Elizabeth Povinelli (2011) claims, and why others simply stay wavering in potentiality. How can we account 
for how her triggers tripped Tara up and she "fell off" or perhaps decisively out of the world, without recuperating her into some already acceptable state of existence? Hayder Al-Mohammad (2013, 212), discussing the precarity of "our fix in the world," writes that being-in-the-world is oscillatory and contingent, as much a matter of keeping a grip on the world as constituted by our relations with other entities as it is about the ways we slip out and disentangle from it. What does it look like to reckon with these situated struggles to both stay in the world and be able to build it anew, as we trace and theorize new political formations?

Tara's case suggests some of the challenges involved in being susceptible to the triggering reactions that can compel important ethical procedures and actions but can also lead to world-collapsing exhaustion. This exhaustion, a critical coordinate of the New Civil Rights era, can preclude the dissonance necessary to move into an ethical and creative mode. On the other hand, Yesi's strategic disengagement from the protest, the Colectiva, and the social world in which she was just regaining her footing suggests the periodic need for this falling out, a retreat to a less volatile world still involved in local ethical formations, for fidelity to enduring relations or concern for the well-being of a community.

Such accounts speak volumes about the moral and material conditions in criminalized settings like East Salinas, conditions that can add critical densities and intensities to practices and experiences of political engagement and activism. It is the primacy of liberal rubrics of participation and activism, however, the recognizable practices of direct action, that can occlude our anthropological understandings of other ways of seeking change and limit support for meaningful actions on the ground, as they may entwine with or seem unrelated to more traditional forms of protest. In tracing the outcroppings and uprisings of the New Civil Rights period, our analyses need to be attuned to grassroots political action that may not be immediately legible as such: the formation of local institutions like healing collectives, the politico-therapeutic aspects of a healing circle, the transformative potential of staying with the trigger.

It is not a linear history of cause-and-effect events that led these women to become activistas, but rather the affectively and ethically affirmed alternative historicities made actual and urgent through their being triggered. Engaging with the rhythmicity of their triggers, the incipient temporalization of social change held by those like Shi, Yesi, and Tara was one of recalibration or reparative thinking (Thomas 2011). It largely focused on dealing with what they had been through, what had happened to them, and what conditions could be shifted without a distinct sense of what that could mean or imply for the future. The triggered 
responses of Mujeres like Shi eventually led toward projects like running healing circles for monolingual Mexican parents at a local public school and for unemployed agricultural workers seeking volunteer hours, collaborating with local artists to elaborate and disseminate each Mujer's healing narrative, running informal academies and forming fellowships of formerly incarcerated youth for juvenile justice reform, among others. These actions are neither straightforwardly resistant nor acquiescent; rather, they intervene on existing institutions and generate new ones to incrementally build a more responsive community infrastructure. They open possibilities for Salinans to engage the work of healing and decriminalization, to realize that their triggers are circumstantial and social, rather than pathological.

The radical potential of the trigger, as figured in East Salinas, begins in its recalibrating of affective historicities, rendering them a source of potential for responding to what will no longer be abided through the forging of new arrangements of collectivity and the situated world-making work of local activism. The broad salience and even ubiquity of triggers, as ethical breakdowns issuing demands for the acknowledgment of a disjunction in eventfulness - something happening, something mattering - indicate a critical mode of apprehending a painful and confounding political present. This present is one that others (anthropologists included) may not entirely or initially share but must reckon with, in the sudden flushes of heat and accelerated heartbeats of loved ones' lived histories of racism that are far from over and done.

\section{ABSTRACT}

In the spring and summer of 2014, both before and after Ferguson, four police officer-involved shootings of unarmed Latino men occurred in the often criminalized and mostly Mexican enclave of East Salinas, California. These deaths at the hands of state agents created significant triggers for many locals-knee-jerk reactions to present stimuli in relation to difficult and diffuse past experiences-generating unprecedented, and sometimes unacknowledged, affective and ethical responses among those who have long abided countless unresolved gang-related deaths in the city. The official downplaying of the deaths as something that "never happens here" stood in contrast to resident responses that stressed the ongoing, if less overt, occurrence of state disregard. Such disparity, as registered in many East Salinans' triggers, indicates the relative eventfulness of state violence that is both slow and ongoing, in addition to occasionally spectacular, in criminalized communities in late liberal America. As a concept imported from psychology in the general mainstreaming of discourses of trauma, triggers are conceptualized here instead as socially generated and ethically generative, a way of marking and making time and transforming the systematic exhaustion of criminalized life into a political resource. Tracing these temporal trip- 
wires ethnographically in East Salinas, in light of a local social project of healing, illuminates the affective and ethical impetus to both political engagement and disengagement in persistently criminalized communities of color as they encounter police homicides and state violence, refracting the proliferating project of making lives matter. [activism; temporality; ethics; morality; trauma; healing; criminalization]

\section{NOTES}

Acknowledgments The research for this article was made possible by the European Research Council and the Amsterdam Institute for Social Science Research. Many thanks to Lex Kuiper, Laura Vermeulen, Sylvia Tidey, and Jarrett Zigon for their engagement with this text through the various stages of its life, to the anonymous reviewers whose comments have significantly strengthened this article, and to Cymene Howe for her guidance during the editorial process.

1. Most Mexican American gangs claim either Norteño (Northerner) or Sureño (Southerner) affiliation. Across Salinas there are dozens of Norteño and Sureño chapters, generally organized by neighborhood. Shi was one of the first women to be initiated into her specific Sureño chapter. Most names in this article have been changed, in keeping with each individual's preference.

2. Salinas is the largest city in Monterey County, and it consistently reports the highest youth homicide rates per capita in the state of California (Violence Policy Center 2015).

3. Throughout this article I make use of Zigon's conceptualization of ethics as reflexive and temporary tactics of self-making, which respond to a situated range of possibilities and issue from breakdowns in mostly nonconsciously enacted morality (Zigon 2007).

4. The high-profile police killings of African Americans in 2014 and 2015 sparked outrage and protest among communities around the country, becoming a flashpoint for related issues like the militarization of law enforcement, mass incarceration, and racial disparity. These responses swelled into an organized effort continuing the work of the mid-century Civil Rights Movement, but in a distinctively contemporary, hence "New," form.

5. Present in thirteen other, similarly underserved but potential-rich neighborhoods statewide, this ten-year investment had been made by the California Endowment, a healthfocused foundation, to foster "the new social justice of health equity." For more on the project, see http://www.calendow.org/building-healthy-communities.

6. California's agricultural zones are among the most gang-active in the state, linked to the effects of land and populations made surplus by the state's postwar political economic restructuring and economic displacements effected by NAFTA (Reynolds 2014; Gilmore 2007).

7. Descargando has layers of meaning beyond the collectives' gloss of "checking in." Most important, the verb descargar means "to unload"-colloquially, the unloading of emotions carried as a heavy load (cargas, baggage).

8. Latinos/as make up 42 percent of the California correctional population, and around 20 percent federally. These are likely underrepresentations, as fragmented institutional reporting mechanisms and the common demarcation of Hispanic as an ethnic, rather than racial, category often leads to un- or undercounted Latino/a demographics (Wagner and Rabuy 2016). As for victims of state violence, the U.S. federal government does not keep an official count of those killed by state agents like police. The FBI's list relies on law enforcement agencies' voluntary reporting of "justifiable homicides," and is as such incomplete. The Guardian (2015) newspaper keeps a running record through its "The Counted" project (see also El Nasser 2015).

9. Despite awareness of a new kind of political formation emerging with Black Lives Matter, labeling this period as new but as a reprisal of the earlier and much mythologized Civil Rights Movement constitutes a form of recognition that is at once legitimizing and 
limiting, as it subjects the emergent movement to certain past-prime and neutralized criteria. The so-called Civil Rights gaze has been conditioned in part by the original movement's co-optation by the rising New Right in the 1970s and its institutionalization in conservative forms by milquetoast state multiculturalism (Bettie 2014; Hall 2005). This conservative gaze stands behind critiques of Black Lives Matters activist techniques: that it is leaderless in its horizontal diffusion and queer rather than heteronormative masculine leadership, or without tangible purpose in its calls to stop killing black people, rather than following a clear pursuit of rights (Kang 2015; Cobb 2016; Alexander 2015). Attachments to old techniques and tropes persist alongside new political articulations.

\section{REFERENCES}

Alexander, Michelle

2015 “Ta-Nehisi Coates's Between the World and Me." New York Times, August 17. http://www.nytimes.com/2015/08/17/books/review/ta-nehisi-coatesbetween-the-world-and-me.html.

Al-Mohammad, Hayder

2013 “Ravelling/Unravelling: Being-in-the-World and Falling-out-of-the-World.” In Biosocial Becomings: Integrating Social and Biological Anthropology, edited by Tim Badiou, Alain Ingold and Gísli Pálsson, 211-28. New York: Cambridge University Press.

2012 Ethics: An Essay on the Understanding of Evil. Translated by Peter Hallward. New Beltrán, Cristina York: Verso. Originally published in 1993.

2010 The Trouble with Unity: Latino Politics and the Creation of Identity. New York: Oxford University Press.

Berlant, Lauren

2007 "Slow Death (Sovereignty, Obesity, Lateral Agency)." Critical Inquiry 33, no. 4: 754-80. https://doi.org/10.1086/521568.

2011 Cruel Optimism. Durham, N.C.: Duke University Press.

Bettie, Julie

2014 Women without Class: Girls, Race, and Identity. Berkeley: University of California Press.

Bonilla, Yarimar, and Jonathan Rosa

2015 "\#Ferguson: Digital Protest, Hashtag Ethnography, and the Racial Politics of Social Media in the United States.” American Ethnologist 42, no. 1:4-17. https://

Brown, Wendy doi.org/10.1111/amet.12112.

2001 Politics Out of History. Princeton, N.J.: Princeton University Press.

2015 Undoing the Demos: Neoliberalism's Stealth Revolution. New York: Zone Books.

Butler, Judith

2015 "What's Wrong With 'All Lives Matter'?" Opinionator blog, New York Times, January 12. http://opinionator.blogs.nytimes.com/2015/01/12/whats-wrongwith-all-lives-matter.

Cacho, Lisa Marie

2012 Social Death: Racialized Rightlessness and the Criminalization of the Unprotected. New York: New York University Press.

Coates, Ta-Nehisi

2015 Between the World and Me. New York: Spiegel and Grau.

Cobb, Jelani

2016 “The Matter of Black Lives.” New Yorker, March 14. http://www.newyorker. Comaroff, Jean com/magazine/2016/03/14/where-is-black-lives-matter-headed.

2011 "Populism and Late Liberalism: A Special Affinity?" Annals of the American Academy of Political and Social Science 637, no. 1: 99-111. https://doi.org/10.1177/ 0002716211406079 . 
Coyne, Jerry A.

2015 “Life Is 'Triggering.' The Best Literature Should Be, Too.” New Republic, May 14. https://newrepublic.com/article/121790/life-triggering-best-literatureshould-be-too.

Day, Elizabeth

2015 “\#BlackLivesMatter: The Birth of a New Civil Rights Movement.” Guardian, July 19. http://www.theguardian.com/world/2015/jul/19/blacklivesmatter-birthcivil-rights-movement.

De Genova, Nicholas

2005 Working the Boundaries: Race, Space, and "Illegality" in Mexican Chicago. Durham, N.C: Duke University Press.

2007 "The Production of Culprits: From Deportability to Detainability in the Aftermath of 'Homeland Security'." Citizenship Studies 11, no. 5: 421-48. https://doi.org/10.1080/13621020701605735.

Dieng, Jamila Bradshaw, Jesús Valenzuela, and Tenoch Ortiz

2016 "Building the We: Healing-Informed Governing for Racial Equity in Salinas." Report. Salinas, Calif.: Race Forward. https://www.raceforward.org/

El Nasser, Haya research/reports/building-we-healing-informed-governing-racial-equity-salinas.

2015 "Police Killings of Latinos Spark Less Outrage than When Victims Are Black." Al-Jazeera, August 13. http://america.aljazeera.com/multimedia/2015/8/ police-killings-of-latinos-spark-less-outrage.html.

Gilmore, Ruth Wilson

2007 Golden Gulag: Prisons, Surplus, Crisis, and Opposition in Globalizing California. Berkeley: University of California Press.

Gordon, Avery F.

2008 Ghostly Matters: Haunting and the Sociological Imagination. 2nd edition. Minneapolis: University of Minnesota Press.

Guardian

2015 "The Counted: People Killed by Police in the United States." Interactive database, June 1. http://www.theguardian.com/us-news/series/counted-uspolice-killings.

Hall, Jacquelyn Dowd

2005 "The Long Civil Rights Movement and the Political Uses of the Past." Journal of American History 91, no. 4: 1233-63. https://doi.org/10.2307/3660172.

Humphrey, Caroline

2008 "Reassembling Individual Subjects: Events and Decisions in Troubled Times." Anthropological Theory 8, no. 4: 357-80. https://doi.org/10.1177/ 1463499608096644.

Kang, Jay Caspian

2015 “Our Demand Is Simple: Stop Killing Us.” New York Times, May 4. http:// www.nytimes.com/2015/05/10/magazine/our-demand-is-simple-stop-killingus.html.

Lukianoff, Greg, and Jonathan Haidt

2015 "The Coddling of the American Mind." Atlantic, September. http:// www.theatlantic.com/magazine/archive/2015/09/the-coddling-of-theamerican-mind/399356.

Povinelli, Elizabeth A.

2011 Economies of Abandonment: Social Belonging and Endurance in Late Liberalism. Durham, N.C.: Duke University Press.

2012 “The Will to Be Otherwise/The Effort of Endurance." South Atlantic Quarterly Ralph, Laurence 111, no. 3: 453-75. https://doi.org/10.1215/00382876-1596236.

2014 Renegade Dreams: Living through Injury in Gangland Chicago. Chicago: University of Chicago Press. 
Rankine, Claudia

2014 Citizen: An American Lyric. Minneapolis, Minn.: Graywolf Press.

Reynolds, Julia

2014 Blood in the Fields: Ten Years Inside California's Nuestra Familia Gang. Chicago: Chicago Review Press.

Santa Cruz, Nicole, Ruben Vives, and Marisa Gerber

2015 "Why the Deaths of Latinos at the Hands of Police Haven't Drawn as Much Attention." Los Angeles Times, July 18. http://www.latimes.com/local/crime/

Stolorow, Robert D. la-me-0718-latino-police-20150718-story.html.

2011 World, Affectivity, Trauma: Heidegger and Post-Cartesian Psychoanalysis. New York: Routledge.

Thomas, Deborah A.

2011 Exceptional Violence: Embodied Citizenship in Transnational Jamaica. Durham, N.C.: Duke University Press.

Violence Policy Center

2015 "Lost Youth: A County-by-County Analysis of 2013 California Homicide Victims Ages 10 to 24." Report. http://www.vpc.org/revealing-the-impacts-of-gunviolence/youth-victimization.

Wagner, Peter, and Bernadette Rabuy

2016 “Mass Incarceration: The Whole Pie 2016." Report. Northampton, Mass.: Prison Policy Initiative. https://www.prisonpolicy.org/reports/pie2016.html.

White, Micah

2016 The End of Protest: A New Playbook for Revolution. Toronto: Knopf Canada.

Zigon, Jarrett

2007 "Moral Breakdown and the Ethical Demand: A Theoretical Framework for an Anthropology of Moralities.” Anthropological Theory 7, no. 2: 131-50. https:// doi.org/10.1177/1463499607077295.

2014 “Temporalization and Ethical Action.” Journal of Religious Ethics 42, no. 3: 44259. https://doi.org/10.1111/jore.12065. 